\title{
Nurses' Opinion on Reporting of Adverse Events during the Process of Nursing Care
}

1 Jelena Hodak

2 Štefanija Kolačko

3 Franka Luetić

1 Department of Anaesthesiology, Resuscitation and Intensive Care, University Hospital Centre Zagreb

2 Ophthalmology Clinic, University Hospital "Sveti Duh"

3 Community Health Centre Zagreb - West

Article received: 14.04 .2017$.

Article accepted: 27.09.2017.

Author for correspondence:

Jelena Hodak, Department of Anaesthesiology,

Resuscitation and Intensive Care, University Hospital

Centre Zagreb, Kišpatićeva 12, 10000 Zagreb. Author for correspondence: e-mail: jhodak5@net.hr

DOI: $10.24141 / 2 / 1 / 1 / 1$

Keywords: adverse events, nursing care, patient safety

\section{Abstract}

Introduction. Patient safety represents the most reliable measure of the quality of work in nursing. The most common adverse events associated with the process of nursing care are bedsores, falls, hospitalacquired infections, insufficient hand hygiene and unwanted adverse effects related to drugs.

Aim. The aim of this study was to investigate the views of respondents on adverse events during the process of nursing care in the University Hospital Centre Osijek.

Respondents and methods. A quantitative crosssectional study was conducted using an anonymous survey on a sample of 100 nurses in February and March 2016, at the clinics for surgery, internal medicine and anaesthesiology, the intensive care unit, emergency room and neurology.

Results. The study showed that nurses actively improve patient safety (82\% of respondents). $71 \%$ of the nurses believe that the mistakes reflect on them, while $67.7 \%$ of the respondents agree with the claim that the mistakes led to positive changes. When an adverse event is reported, $74.2 \%$ of nurses feel as if they are the ones being reported, and not the problem itself. After they make changes to improve patient safety, $83.5 \%$ of the nurses evaluate their effectiveness. $33.4 \%$ of the respondents claim that there are patient safety issues at their ward, and 49 $(50 \%)$ of the respondents claim that the procedure and the system are efficient at preventing mistakes. 
Most respondents (57.1\%) rated patient safety as acceptable. In similar studies that were conducted in US hospitals, there was generally a higher level of the patient safety culture by several grade points.

Conclusion. Nurses agree that the patient safety culture regarding adverse events in the process of nursing care in the University Hospital Centre Osijek is acceptable, and that they are responsible for protecting and improving patient safety.

\section{Introduction}

Patient safety represents the most reliable measure of the quality of work in nursing. The World Health Organization defines patient safety as "prevention, elimination and improvement of protection against adverse events during the process of health care" (1). Adverse events occur in every medical procedure and at all levels of the health system. The most common errors in nursing are related to patient falls, administration of drugs, bedsores, insufficient hand hygiene, and hospital infections. In the most developed countries, despite the usage of modern technology, 10\% to $12 \%$ of patients are exposed to incidents of which as many as half could have been prevented.

\subsection{The European Council on patient safety and quality of health care}

The Council of the European Union adopted the guidelines on patient safety and quality of health care in 2009. That marked the start of an improvement program in the EU Member States which states the following:

- support the establishment and development of national policies and programs for patient safety

- increase the awareness about institutions responsible for patient safety

- include patient safety as a priority in all health policies and programs

- allow reviewing and updating of patient safety standards and best practices that are carried out in the territory of Member States

- encourage health care organizations to take on an active role
- present the risks and safety measures which are applied

- learn about complaint procedures and remedies

- develop patient competencies (knowledge, skills and attitudes required for the safe use of health care)

- collect additional recommendations for infection prevention and control (2).

\subsection{Croatian Agency for Quality and Accreditation in Health Care and Social Welfare}

Unexpected adverse events are defined by the Regulation on Health Care Standards and the Manner of Their Application (Official Gazette 79/11), which all health institutions, companies and private health workers must follow and report on every three months to the Ministry and the Agency for Quality and Accreditation in Health Care and Social Welfare. A report of other adverse events should be submitted every six months (3). Unexpected adverse events are:

- a surgical procedure performed on the wrong patient

- a surgical procedure performed on the wrong body part

- an instrument or object left on the site of a surgical procedure due to which additional surgery or procedure must be performed

- a transfusion reaction due to $\mathrm{ABO}$ incompatibility

- death, coma or severe damage to health due to incorrect pharmacotherapy

- death of a mother or a serious illness associated with childbirth

- kidnapping of a newborn

- discharging a newborn to a wrong family

- death or a permanent disability of a healthy newborn, whose birth weight is greater than 2500 g, which are not associated with a congenital disease

- severe neonatal jaundice (bilirubin > $513 \mu \mathrm{mol} / \mathrm{L}$ )

- suicide or attempted suicide in a medical institution or a company, or within 72 hours of patient discharge

- wrong body region radiotherapy

- radiotherapy with a dose of $25 \%$ above the planned one. 
Other adverse events (patient safety indicators):

- standardised hospital mortality rate

- postoperative wound infection

- insufficient hand hygiene

- postoperative pulmonary embolism or deep vein thrombosis

- postoperative bleeding or hematoma

- adverse drug side effects

- obstetric trauma - vaginal delivery without instruments

- birth trauma - injury of a newborn

- postoperative hip fracture

- fall in a medical institution

- decubital ulcer

- side effects of antipsychotic treatment.

The Agency for Quality and Accreditation in Health Care and Social Welfare has established data collection on adverse events in health care institutions via the IZ-AAZ-NND form which is on the Agency's website. The data gathered on unexpected adverse events have been analysed since 2012 .

\subsection{Croatian Act on Quality of Health Care}

Article 5 of the Act on Quality of Health Care (Official Gazette 107/07) states the following regarding the safety of patients and staff: "A health institution, a company or a private health worker must have ways of identification and detection of the prevalence and severity of incidents that affect or threaten the safety of patients and staff. This must include medical errors and adverse events" (4). Health institutions, companies and private health workers must have a documented system of patient and staff safety which should include the following: detection and reporting, preventive and corrective actions, a defined procedure for risk reduction, implementation of action plans, continuous monitoring to ensure the effectiveness of actions, the assessment of the safety of patients and staff carried out by the head or the responsible person, the policy and practice of informing patients and/ or their families about unexpected adverse events (4).

\subsection{Croatian Society for Patient Safety}

The Society's main goal is to improve patient safety by researching and reviewing the current level of patient safety, continuously improving the patient safe- ty culture by ensuring the availability of all methods and tools for improving patient safety and encouraging the application of these tools and methods at all levels of health care and social welfare.

The Society's main goals include the following activities:

- promotion of the importance of patient safety by organizing educational, professional and public meetings

- regular collection of the latest, complete and high-quality information on methods and tools for improving patient safety and their presentation to the members of the Society and the general public in order to improve the exchange of information

- supporting experts and people involved in improving patient safety, especially young people, by organizing lectures, courses, seminars and workshops

\subsection{Society for Quality - Croatian Nurses Association}

In 2015, the Society for Quality - Croatian Nurses Association organised a conference aimed at keeping and analysing previously obtained nursing documentation. The data on risks associated with the falls, bedsores and nosocomial infections, the measures taken and the improvements that emerged on the basis of those analyses was obtained from different medical institutions. The number of units for quality has been increasing in hospitals and nurses are integral, equal members. So, there are nurses for education, nosocomial infections and a nurse for discharging patients from the hospital (5).

\subsection{Creating a patient safety culture}

The American Nurses Association (ANA) defines safety culture as one in which the fundamental values and conduct are a result of a collective and continuous involvement of organizational leadership and workers in emphasizing safety over competing objectives (6). The characteristics of a positive safety culture are openness and mutual trust when discussing safety issues and solutions without blaming the individual. Confident staff and different levels of skills in the learning environment in which health professionals can learn from the mistakes and actively reveal systemic weaknesses contribute to transparency and accountability (6). Nurses have an ethical obliga- 
tion to prevent and deal with adverse events. Ethical theories are the basis of this view and suggest discovering mistakes in patient treatment (7).

\subsection{Adverse events associated with the process of nursing care}

The most common adverse events associated with the process of nursing care are bedsores, patient falls, nosocomial infections, insufficient hand hygiene and unwanted drug side effects. We will go into more detail later on in the paper.

\subsubsection{Bedsores}

In 2009, the European and US National Pressure UIcer Advisory panels (EPUAP and NPUAP) announced first clinical guidelines for the prevention and treatment of bedsores aimed at improving care of patients with bedsores in all EU countries and the world. NPUAP brought a consensus on a common methodology for monitoring in 1989. Bedsore frequency varies from $1 \%$ to $11 \%$, while the prevalence in hospitalised population is from $5 \%$ to $15 \%, 39 \%$ in chronic patients, from $3 \%$ to $20 \%$ in institutions for elderly people, and around $20 \%$ in home care (8). The declaration on the prevention of bedsores as a universal human right was adopted in Rio de Janeiro in November 2011. It describes bedsores as an adverse event and a main threat to patient safety within the health system of any institution and any country in the world.

\subsubsection{Patient falls in a medical institution}

Monitoring the rate of patient falls and the application of indicators of quality health care as well as a planned and systematic introduction of changes in the work process ensure safe and efficient health services and significantly reduce the possibility of occurrence of adverse events (9). The Morse Fall Scale is used most often, but other tools can be used which are adapted to patients' needs and specifics of a health institution. Nurses and other health workers should have clear guidelines on the methods of reporting the adverse events and the time frame in which the adverse event should be reported.

\subsubsection{Nosocomial infections}

It is estimated that around 4.1 million patients contract an infection associated with health care every year in the European Union (10). A direct result of these infections is about 37,000 deaths, with additional 110,000 deaths caused by indirect effects (10). By increasing mortality and permanent damages, those infections prolong hospitalization and increase costs. The infection associated with health care is every patient infection that occurs independently of the primary disease, i.e. it is any infection of a healthy person which is the result of diagnosis, treatment or nursing care, which developed during treatment and nursing care, after a diagnostic or therapeutic procedure, or after discharge from the hospital or other health care institution (10). In developed countries' health institutions, $5 \%$ to $10 \%$ of patients in hospitals get one or more hospital infections. In the intensive care units, a portion of patients affected by hospital infections is up to $30 \%$ (10).

\subsubsection{Insufficient hand hygiene}

The World Health Organization announced actions that are based on scientific evidence regarding hand hygiene in health care to support health institutions in improving hand hygiene and thus reduce infections associated with health care. Although hand hygiene is considered the single most important intervention in the prevention of nosocomial infections, research shows poor compliance of health care professionals (10). It is a complex problem which involves elements of lack of motivation and ignorance about the importance of hand hygiene. This may be due to a lack of personnel, unavailability of resources for hand hygiene and unacceptable agents for hand hygiene.

\subsubsection{Adverse side effects of drugs}

A side effect of a drug is any harmful and unwanted reaction to a medicine which is properly administrated in therapeutic doses in the approved indication (11). A serious drug side effect/adverse event is any harmful and undesirable sign, symptom or disease associated with the time of the drug administration, and which does not have to be consequentially related to the drug administration. Side effects include the death of a person, a life-threatening condition, the need for hospitalization or prolongation of current hospitalization, a permanent or severe disability or a disability, congenital anomaly/birth defect and other medically important conditions estimated by the applicant (11). Error in the drug administration in the process of nursing care is when a drug is admin- 
istered to the wrong patient, in the wrong dosage, at the wrong time or by wrong application.

\subsection{Measures important for the prevention of adverse events in the nursing practice}

The patient is at the heart of the quality system. Therefore, the health institution and its employees must ensure conditions which contribute to their health and safety. Measures for the prevention of adverse events in nursing practice, with quality control of nursing care, include the following: integration and evaluation of prevention programs in relation to falls and bedsores, numerous interventions, a multidisciplinary approach, education of the staff, patients and collaboration with families, increasing awareness of nurses, data collection, trend analysis, reporting on adverse events in professional meetings as well as changes in the work environment.

\subsection{Risk management in the process of nursing care}

There is not enough staff in the health system to successfully implement measures regarding patient safety into everyday practice. Dedication is particularly important to incorporate the desired safety culture throughout the organisation. Quality infrastructure should be supported with human resources necessary to successfully improve the quality of nursing care. It is important that the highly educated nurses, in charge of the quality of the work, be at specific positions because they encourage changes in terms of improving health care quality, patient safety and risk management in the quality system (12).

\section{Aim of the paper}

The aim of this paper is to examine the opinions subjects have for reporting of adverse events during the process of nursing care in the University Hospital Centre Osijek.

\section{Subjects and methods}

\subsection{Research structure}

A quantitative cross-sectional study was conducted during February and March 2016.

\subsection{Subjects}

The sample consists of one hundred (100) participants - nurses of all levels of education and jobs, employed in the University Hospital Centre Osijek at the Departments of Surgery, Anaesthesia and Intensive Care, Internal Medicine, Neurology and Maxillofacial Surgery. Each participant was familiar with the purpose of the research and gave voluntary consent to participate. Confidentiality of the information was ensured by using sealed envelopes. The criteria for the inclusion into the research was the vocation of a nurse, regardless of the level of education completed. None of the subjects were excluded during the study nor were there any subsequently included subjects. The method of choosing the nurses sample for the research was random.

\subsection{Methods}

The survey instrument was an anonymous Likert poll for surveying on a scale from 1 to 5 . The survey was partly based on a survey which was systematically used for research on the patient safety culture in US hospitals. It consisted of ten parts regarding the working environment (17 questions), the supervisor (4 questions), communication (6 questions), the frequency of reporting of adverse events in the department ( 2 questions), the assessment of patient safety (1 question), the patient safety culture in the hospital (3 questions), the frequency of reporting of adverse events in the last 12 months (1 question), general information about the subjects and comments on subjects related to adverse events that existed in their work environment.

\subsubsection{Statistical methods}

Normality of the distribution was tested by the Kolmogorov-Smirnov test. Mean values of the continuous variables are expressed with median and inter- 
quartile range, and nominal indicators are expressed with an absolute and relative number. Differences between categorical variables were tested by the Fisher's exact test. The Mann-Whitney test was used to determine the difference between two independent groups. Originally written applications for the databases were used, and the SPSS statistical package for Windows (version 17.0, Carry, NY, USA) with significance level $\alpha=0.05$. All $P$ values are two-sided.

\section{Results}

\subsection{Subjects' characteristics}

The study was conducted on 100 subjects, of which $19 \%$ have been working in a hospital for less than a year, $29 \%$ of them for one to ten years, and $52 \%$ of them have been working for 11 to 20 years. 31\% of subjects hold a Bachelor of Nursing degree, $62 \%$ of subjects are nurses who completed a secondary education, and $7 \%$ of the subjects have a Master of Nurs- ing degree. The same percentage of subjects - 50\% are from surgical (surgery and ICU, anaesthesiology) and non-surgical departments (internal medicine and neurology).

\subsection{Workplace}

60 subjects (61.2\%) agree with the claim that people support each other, and 86 subjects (86\%) state that they work as a team when there is a lot of work needed to be done quickly. 52 subjects (52\%) agree with the claim that people treat each other with respect, and 61 subjects (61\%) work longer than they have to in order to provide the best care to the patient. There are no significant differences in the self-evaluated claims regarding the workplace, inter-human relationships and working in a team by years of work experience (Table 1 ) or by education level (Table 2).

80 subjects (82\%) agree that nurses are active in improving patient safety, and 18 subjects (18.5\%) say that they use substitute nurses which is the best for patient care. 71 (71\%) of nurses feel that mistakes reflect on them, and 65 subjects (67.7\%) agree with the claim that mistakes led to positive improvements. 72 subjects $(72.7 \%)$ agree that serious mistakes do not happen and that it is all just a coincidence, and 70 subjects $(72.1 \%)$ state that another ward helps out if

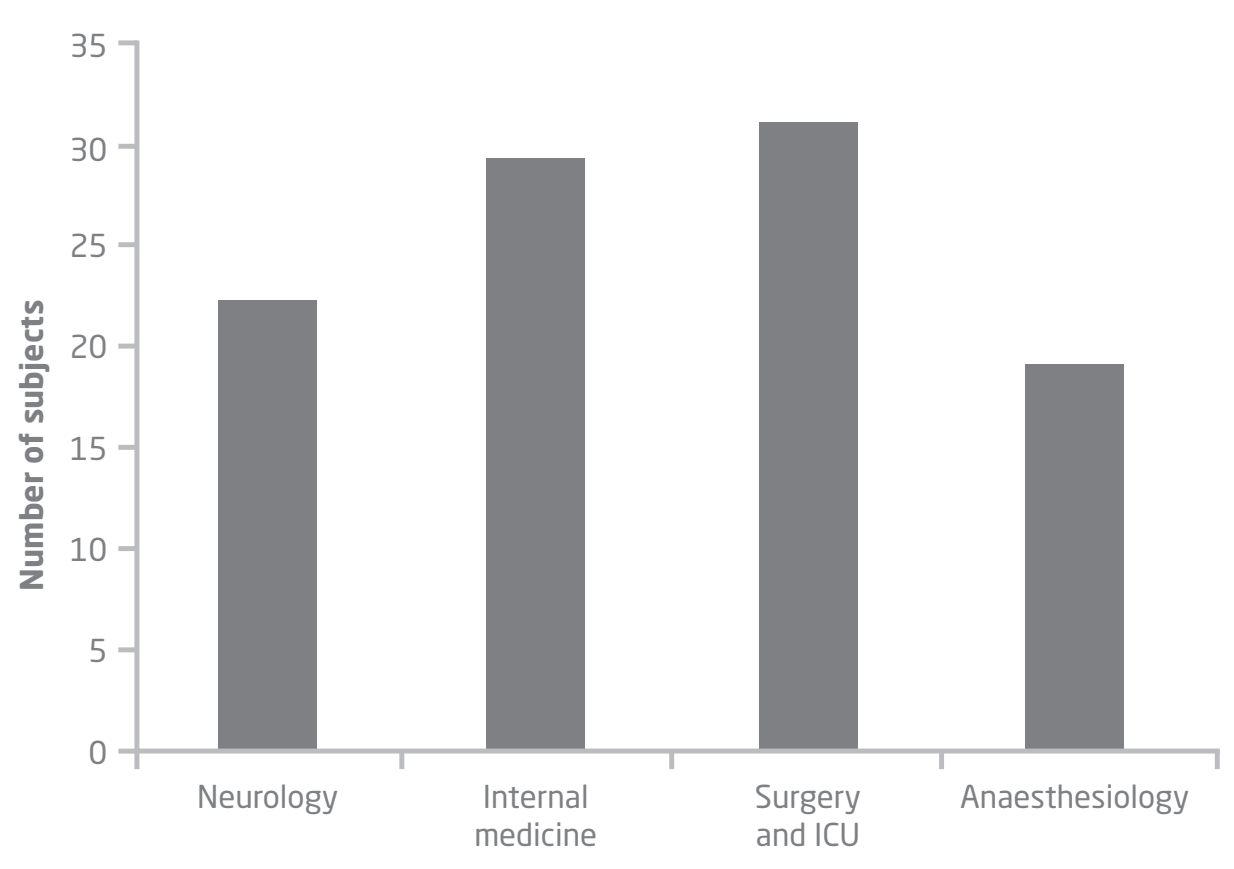

Figure 1. Subjects by their workplace 
Table 1. Mean value of self-evaluation claims regarding the workplace by years of work experience

\begin{tabular}{|c|c|c|c|c|c|}
\hline & \multicolumn{4}{|c|}{$\begin{array}{l}\text { Median (Interquartile range) by the amount of work } \\
\text { experience }\end{array}$} & \multirow{2}{*}{ p* } \\
\hline & $<1$ year & $\begin{array}{l}1-10 \\
\text { years }\end{array}$ & $\begin{array}{l}11-20 \\
\text { years }\end{array}$ & Total & \\
\hline People support each other in this ward. & $\begin{array}{c}4 \\
(2-4)\end{array}$ & $(2-4)$ & $\begin{array}{c}4 \\
(2-4)\end{array}$ & $\begin{array}{c}4 \\
(2-4)\end{array}$ & 0.636 \\
\hline We have enough staff. & $\begin{array}{c}2 \\
(1-3)\end{array}$ & $(1-3)$ & $\begin{array}{c}2 \\
(1-2)\end{array}$ & $(1-2)$ & 0.546 \\
\hline $\begin{array}{l}\text { We work together as a team when there is a } \\
\text { lot of work that needs to be done. }\end{array}$ & $\begin{array}{c}4 \\
(4-4)\end{array}$ & $\begin{array}{c}4 \\
(4-4)\end{array}$ & $\begin{array}{c}4 \\
(4-4)\end{array}$ & $\begin{array}{c}4 \\
(4-4)\end{array}$ & 0.839 \\
\hline People treat each other with respect. & $(2-4)$ & $\begin{array}{c}4 \\
(2-4)\end{array}$ & $\begin{array}{c}4 \\
(2-4)\end{array}$ & $\begin{array}{c}4 \\
(2-4)\end{array}$ & 0.820 \\
\hline $\begin{array}{l}\text { Ward staff works longer than it is necessary } \\
\text { to provide the best care to the patient. }\end{array}$ & $\begin{array}{c}4 \\
(2-4)\end{array}$ & $\begin{array}{c}3 \\
(2-4)\end{array}$ & $\begin{array}{c}4 \\
(3-4)\end{array}$ & $\begin{array}{c}4 \\
(2-4)\end{array}$ & 0.317 \\
\hline
\end{tabular}

\section{Table 2. Mean value of self-evaluation claims regarding the workplace by education level}

Median (Interquartile range) by education level

\begin{tabular}{|c|c|c|c|c|}
\hline & $\begin{array}{l}\text { Bachelor or Master } \\
\text { of Nursing degree }\end{array}$ & Nurse & Total & $\mathbf{p}^{*}$ \\
\hline People support each other in this ward. & $\begin{array}{c}4 \\
(2-4)\end{array}$ & $\begin{array}{c}4 \\
(2-4)\end{array}$ & $\begin{array}{c}4 \\
(2-4)\end{array}$ & 0.642 \\
\hline We have enough staff. & $(1-2)$ & $\begin{array}{c}2 \\
(1-2.25)\end{array}$ & $(1-2)$ & 0.876 \\
\hline $\begin{array}{l}\text { We work together as a team when there is a lot of } \\
\text { work that needs to be done. }\end{array}$ & $\begin{array}{c}4 \\
(4-4.25)\end{array}$ & $\begin{array}{c}4 \\
(4-4)\end{array}$ & $\begin{array}{c}4 \\
(4-4)\end{array}$ & 0.087 \\
\hline People treat each other with respect. & $\begin{array}{c}3.5 \\
(2-4)\end{array}$ & $\begin{array}{c}4 \\
(2-4)\end{array}$ & $(2-4)$ & 0.542 \\
\hline $\begin{array}{l}\text { Ward staff works longer than it is necessary to } \\
\text { provide the best care to the patient. }\end{array}$ & $\begin{array}{c}4 \\
(2-4)\end{array}$ & $\begin{array}{c}4 \\
(2.5-4)\end{array}$ & $\begin{array}{c}4 \\
(2-4)\end{array}$ & 0.667 \\
\hline Mann-Whitney U test & & & & \\
\hline
\end{tabular}

a ward is really busy. If the adverse event is reported, 72 subjects $(74.2 \%)$ feel like they are the ones that are reported, and not the event. After changes to improve patient safety, 81 subjects (83.5\%) assess their efficiency. Significantly more subjects, who have more than one year of work experience, agree with the claim that another ward helps out when a ward is busy, compared to subjects who only have a maximum of one year of work experience (KruskalWallis test, $p=0.013$ ) (Table 3). Subjects holding a Bachelor or Master of Nursing degree feel that the report of the adverse event is more a rebuke of them than a report of the event (Mann-Whitney $U$ test, $p=$ 0.032) (Table 4).

\subsection{Superior}

72 subjects $(72.7 \%)$ state that the superior commends them when he/she sees that the work is carried out in accordance with the established procedures of patient safety, and 81 subjects (81.8\%) agree with the statement that the superior seriously considers proposals from their colleagues to improve patient safety. 55 subjects (56.1\%) agree that their superior wants the job to be done quicker in high stress situations, even if it means shortening the procedure. Subjects holding a Bachelor or Master of Nursing degree agree significantly more with the statement that when the stress increases the supe- 


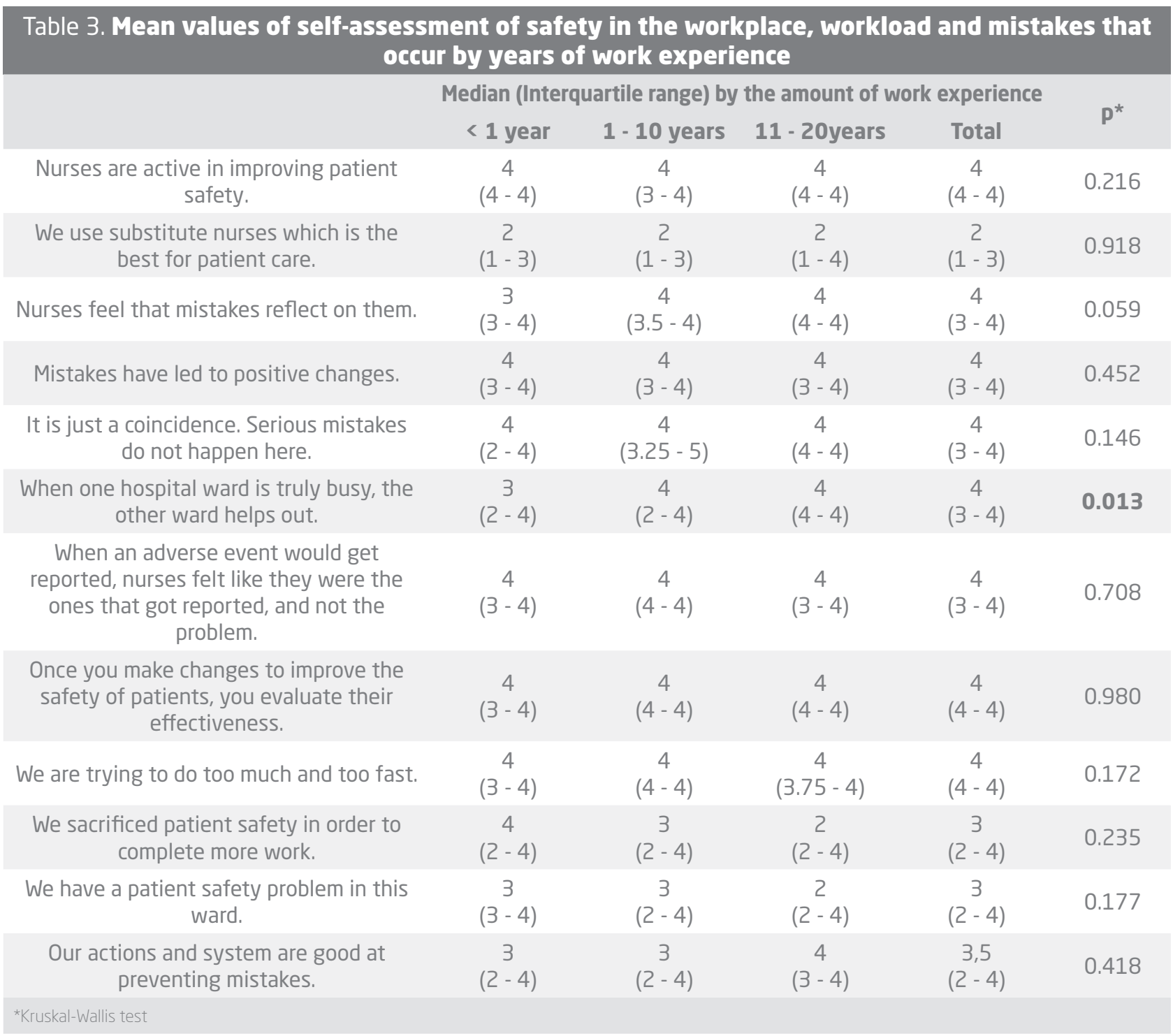

rior wants the job to be done faster, even if it means shortening the procedure (Mann-Whitney $\mathrm{U}$ test, $\mathrm{p}=$ 0.021) (Table 5).

\subsection{Communication}

41 subjects (41.8\%) agree with the claim that feedback is given regarding the changes on the basis of a report of an adverse event, and 79 subjects (79.8\%) agree with the claim that nurses speak freely if they notice something that may negatively impact patient care. 50 subjects $(49.5 \%)$ agree with the claim that they are informed about the mistakes which occur in the ward, and 53 subjects (53.6\%) agree with the claim that nurses can freely ask about the superior's decisions. 72 subjects (72.7\%) agree with the claim that they can talk about the ways to prevent mistakes in the hospital, and 10 subjects (10.1\%) state that nurses are afraid to ask for advice when they are not doing things according to the procedure (Table 6).

\subsection{The frequency of adverse events reported in the hospital}

45 subjects (45.9\%) state that they, usually or always, report mistakes which directly affect the patient, and 38 subjects (39.6\%) state that they, usually or always, report mistakes which cannot potentially harm the patient (Table 7). 


\section{Table 4. Mean values of self-assessment of safety in the workplace, workload and mistakes that occur by education level}

\begin{tabular}{|c|c|c|c|c|}
\hline & \multicolumn{4}{|c|}{ Median (Interquartile range) by education level } \\
\hline & $\begin{array}{l}\text { Bachelor or } \\
\text { Master of } \\
\text { Nursing degree }\end{array}$ & Nurse & Total & $\mathbf{p}^{*}$ \\
\hline Nurses are active in improving patient safety. & $\begin{array}{c}4 \\
(3-4)\end{array}$ & $\begin{array}{c}4 \\
(4-4)\end{array}$ & $\begin{array}{c}4 \\
(4-4)\end{array}$ & 0.689 \\
\hline $\begin{array}{l}\text { We use substitute nurses which is the best for patient } \\
\text { care. }\end{array}$ & $\begin{array}{c}2 \\
(1-2.25)\end{array}$ & $\begin{array}{c}2 \\
(1-3)\end{array}$ & $\begin{array}{c}2 \\
(1-3)\end{array}$ & 0.597 \\
\hline Nurses feel that mistakes reflect on them. & $\begin{array}{c}4 \\
(4-4)\end{array}$ & $\begin{array}{c}4 \\
(3-4)\end{array}$ & $\begin{array}{c}4 \\
(3-4)\end{array}$ & 0.165 \\
\hline Mistakes have led to positive changes. & $\begin{array}{c}4 \\
(3-4)\end{array}$ & $\begin{array}{c}4 \\
(3-4)\end{array}$ & $\begin{array}{c}4 \\
(3-4)\end{array}$ & 0.226 \\
\hline $\begin{array}{l}\text { It is just a coincidence. Serious mistakes do not happen } \\
\text { here. }\end{array}$ & $\begin{array}{c}4 \\
(3.75-4.25)\end{array}$ & $\begin{array}{c}4 \\
(3-4)\end{array}$ & $\begin{array}{c}4 \\
(3-4)\end{array}$ & 0.431 \\
\hline $\begin{array}{l}\text { When one hospital ward is truly busy, the other ward } \\
\text { helps out. }\end{array}$ & $\begin{array}{c}4 \\
(3-4)\end{array}$ & $\begin{array}{c}4 \\
(3-4)\end{array}$ & $\begin{array}{c}4 \\
(3-4)\end{array}$ & 0.919 \\
\hline $\begin{array}{c}\text { When an adverse event would get reported, nurses felt } \\
\text { like they were the ones that got reported, and not the } \\
\text { problem. }\end{array}$ & $\begin{array}{c}4 \\
(4-4)\end{array}$ & $(3-4)$ & $\begin{array}{c}4 \\
(3-4)\end{array}$ & 0.032 \\
\hline $\begin{array}{l}\text { Once you make changes to improve the safety of } \\
\text { patients, you evaluate their effectiveness. }\end{array}$ & $\begin{array}{c}4 \\
(4-4)\end{array}$ & $\begin{array}{c}4 \\
(4-4)\end{array}$ & $\begin{array}{c}4 \\
(4-4)\end{array}$ & 0.502 \\
\hline We are trying to do too much and too fast. & $\begin{array}{c}4 \\
(4-4)\end{array}$ & $\begin{array}{c}4 \\
(3-4)\end{array}$ & $\begin{array}{c}4 \\
(4-4)\end{array}$ & 0.244 \\
\hline $\begin{array}{l}\text { We sacrificed patient safety in order to complete more } \\
\text { work. }\end{array}$ & $\begin{array}{c}3 \\
(2-4)\end{array}$ & $\begin{array}{c}3 \\
(2-4)\end{array}$ & $\begin{array}{c}3 \\
(2-4)\end{array}$ & 0.645 \\
\hline We have a patient safety problem in this ward. & $\begin{array}{c}2 \\
(2-4)\end{array}$ & $\begin{array}{c}3 \\
(2-4)\end{array}$ & $\begin{array}{c}3 \\
(2-4)\end{array}$ & 0.281 \\
\hline $\begin{array}{l}\text { Our actions and system are good at preventing } \\
\text { mistakes. }\end{array}$ & $\begin{array}{c}3 \\
(2-4)\end{array}$ & $\begin{array}{c}4 \\
(2-4)\end{array}$ & $\begin{array}{c}3.5 \\
(2-4)\end{array}$ & 0.919 \\
\hline
\end{tabular}

\section{Table 5. Mean values of self-evaluation of the superior's procedures by education level}

\section{Median (Interquartile range)}

My superior

commends when he/shesees that the work takes place in accordance with the established methods of patient safety.

... seriously considers nurses' proposals for improving patient safety.

... when stress increases, he/she wantsme to work faster, even if that means shortening the procedure. ...considers patient safety as a problem that occurs more frequently.

\section{Bachelor or \\ Master of Nursing degree}

$\begin{array}{ccc}4 & 4 & 4 \\ (3-4) & (3.5-4) & (3-4)\end{array}$

$\begin{array}{ccc}4 & 4 & 4 \\ (4-4.25) & (4-4) & (4-4) \\ 4 & 3 & 4 \\ (3-4) & (2-4) & (2-4) \\ 4 & 3 & 3 \\ (2.75-4) & (2-4) & (2-4)\end{array}$

p*

Total

4

$$
\text { (1) }
$$

0.082

0.021

3

$2-4)$ 
There is no significant difference in self-assessment of the events reported in the hospital by the amount of work experience or education level (Table 8).

\subsection{Patient safety rating}

Most of the subjects $-44(57.1 \%)$ in total - rated patient safety as acceptable, and 21 subjects (27.3\%) rated it as very good. Only two subjects rated patient safety as excellent (Figure 2).

\section{Table 6. Subject responses regarding communication}

\begin{tabular}{|c|c|c|c|c|c|c|}
\hline & \multicolumn{6}{|c|}{ Number (\%) of subjects } \\
\hline & $\begin{array}{l}\text { Strongly } \\
\text { disagree }\end{array}$ & Disagree & Neutral & Agree & $\begin{array}{l}\text { Strongly } \\
\text { agree }\end{array}$ & Total \\
\hline $\begin{array}{c}\text { Feedback is given regarding the } \\
\text { changes on the basis of a report of an } \\
\text { adverse event. }\end{array}$ & $\begin{array}{c}1 \\
(1)\end{array}$ & $\begin{array}{c}10 \\
(10.2)\end{array}$ & $\begin{array}{c}46 \\
(46.9)\end{array}$ & $\begin{array}{c}29 \\
(29.6)\end{array}$ & $\begin{array}{c}12 \\
(12.2)\end{array}$ & $\begin{array}{c}98 \\
(100)\end{array}$ \\
\hline $\begin{array}{l}\text { Nurses speak freely if they notice } \\
\text { something that may have a negative } \\
\text { impact on patient care. }\end{array}$ & 0 & $\begin{array}{l}3 \\
(3)\end{array}$ & $\begin{array}{c}17 \\
(17.2)\end{array}$ & $\begin{array}{c}55 \\
(55.6)\end{array}$ & $\begin{array}{c}24 \\
(24.2)\end{array}$ & $\begin{array}{c}99 \\
(100)\end{array}$ \\
\hline $\begin{array}{l}\text { We are informedabout mistakes made } \\
\text { in the ward. }\end{array}$ & 0 & $\begin{array}{c}8 \\
(8.1)\end{array}$ & $\begin{array}{c}41 \\
(41.4)\end{array}$ & $\begin{array}{c}33 \\
(33.3)\end{array}$ & $\begin{array}{c}17 \\
(17.2)\end{array}$ & $\begin{array}{c}99 \\
(100)\end{array}$ \\
\hline $\begin{array}{l}\text { Nurses can freely ask about the } \\
\text { superior's decisions. }\end{array}$ & 0 & $\begin{array}{c}5 \\
(5.1)\end{array}$ & $\begin{array}{c}41 \\
(41.4)\end{array}$ & $\begin{array}{c}38 \\
(38.4)\end{array}$ & $\begin{array}{c}15 \\
(15.2)\end{array}$ & $\begin{array}{c}99 \\
(100)\end{array}$ \\
\hline $\begin{array}{l}\text { We can talk about the ways to } \\
\text { prevent mistakes in this hospital. }\end{array}$ & 0 & $\begin{array}{c}5 \\
(5.1)\end{array}$ & $\begin{array}{c}22 \\
(22.2)\end{array}$ & $\begin{array}{c}51 \\
(51.5)\end{array}$ & $\begin{array}{c}21 \\
(21.2)\end{array}$ & $\begin{array}{c}99 \\
(100)\end{array}$ \\
\hline $\begin{array}{l}\text { Nurses are afraid to ask for advice } \\
\text { when they are not doing things } \\
\text { according to the procedure. }\end{array}$ & $\begin{array}{c}21 \\
(21.2)\end{array}$ & $\begin{array}{c}52 \\
(52.5)\end{array}$ & $\begin{array}{c}16 \\
(16.2)\end{array}$ & $\begin{array}{c}7 \\
(7.1)\end{array}$ & $\begin{array}{c}3 \\
(3)\end{array}$ & $\begin{array}{c}99 \\
(100)\end{array}$ \\
\hline
\end{tabular}

\section{Table 7. Subject responses regarding the frequency of adverse events}

\begin{tabular}{|c|c|c|c|c|c|c|}
\hline & \multicolumn{6}{|c|}{ Number $(\%)$ of subjects } \\
\hline & Never & Rarely & Sometimes & $\begin{array}{c}\text { Most of the } \\
\text { time }\end{array}$ & Always & Total \\
\hline $\begin{array}{l}\text { How often is a mistake, which } \\
\text { directly affects the patient, } \\
\text { reported? }\end{array}$ & 0 & $\begin{array}{c}6 \\
(6.1)\end{array}$ & $\begin{array}{c}47 \\
(48)\end{array}$ & $\begin{array}{c}26 \\
(26.5)\end{array}$ & $\begin{array}{c}19 \\
(19.4)\end{array}$ & $\begin{array}{c}98 \\
(100)\end{array}$ \\
\hline $\begin{array}{c}\text { How often is a mistake, which } \\
\text { does not potentially harm the } \\
\text { patient, reported? }\end{array}$ & $\begin{array}{c}5 \\
(5.2)\end{array}$ & $\begin{array}{c}20 \\
(20.8)\end{array}$ & $\begin{array}{c}33 \\
(34.4)\end{array}$ & $\begin{array}{l}24 \\
(25)\end{array}$ & $\begin{array}{c}14 \\
(14.6)\end{array}$ & $\begin{array}{c}96 \\
(100)\end{array}$ \\
\hline
\end{tabular}

\section{Table 8. Mean values of self-assessment of adverse events by years of work experience}

\begin{tabular}{|c|c|c|c|c|c|}
\hline & \multicolumn{4}{|c|}{ Median (Interquartile range) } & \multirow[b]{2}{*}{$\mathbf{p}^{*}$} \\
\hline & < 1 year & $\begin{array}{l}1-10 \\
\text { years }\end{array}$ & $\begin{array}{l}11-20 \\
\text { years }\end{array}$ & Total & \\
\hline $\begin{array}{l}\text { How often is a mistake, which directly } \\
\text { affects the patient, reported? }\end{array}$ & $\begin{array}{c}3 \\
(3-4)\end{array}$ & $\begin{array}{c}3 \\
(3-4)\end{array}$ & $\begin{array}{c}3.5 \\
(3-4.75)\end{array}$ & $\begin{array}{c}3 \\
(3-4)\end{array}$ & 0.379 \\
\hline $\begin{array}{l}\text { How often is a mistake, which does not } \\
\text { potentially harm the patient, reported? }\end{array}$ & $(3-4)$ & $(3-4)$ & $\begin{array}{l}3 \\
(2.75-4)\end{array}$ & $\begin{array}{c}3 \\
(2-4)\end{array}$ & 0.279 \\
\hline
\end{tabular}




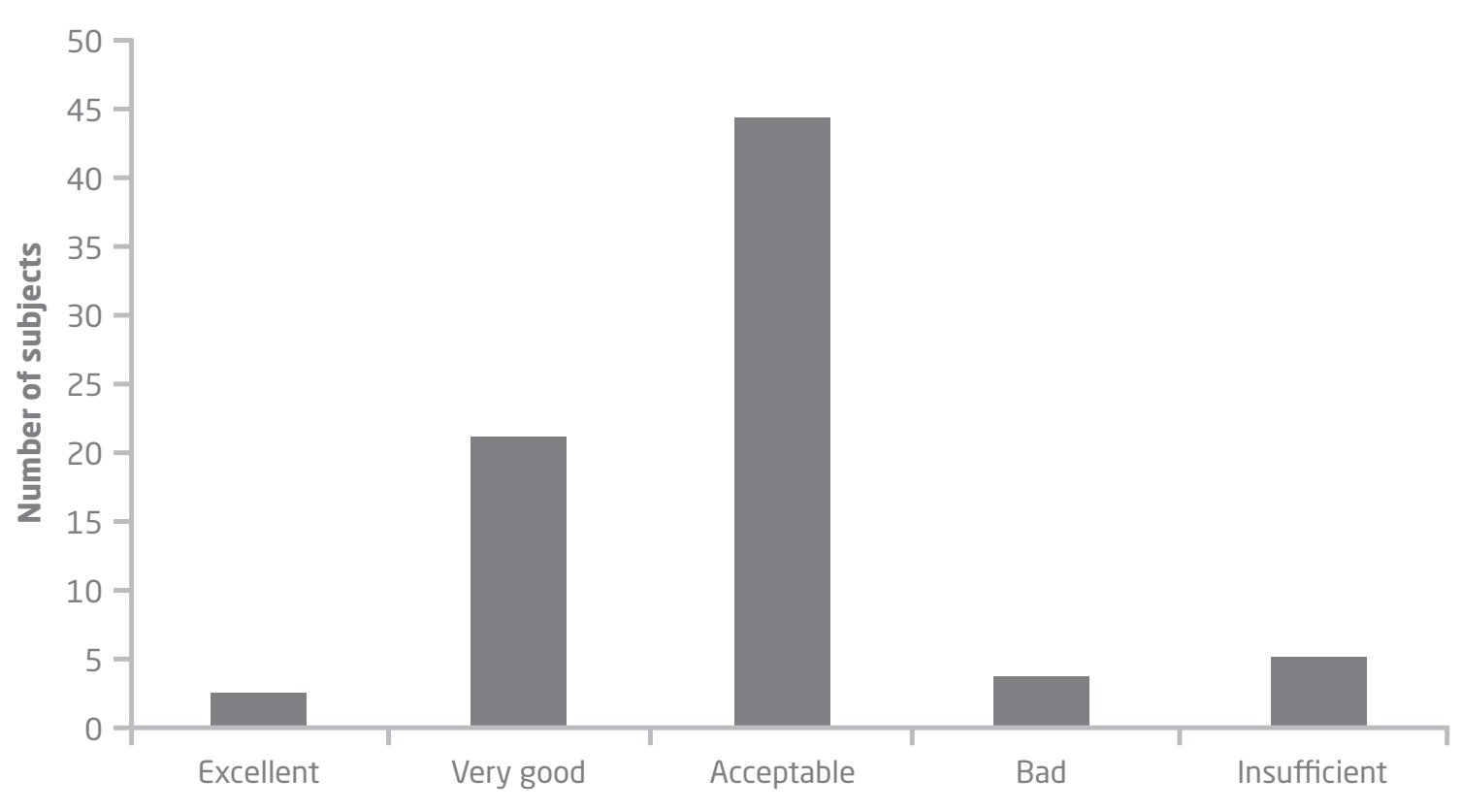

Figure 2. Distribution of subjects by the assessment of patient safety

\subsection{Hospital in which they work}

39 subjects (39.8\%) strongly agree or agree with the claim that the hospital management provides a working environment which promotes patient safety. 65 subjects (65.6\%) agree with the claim that hospital wards cooperate, while 52 subjects $(53.6 \%)$ state that the problems are "covered up" when transferring from one ward to another (Table 9).

34 subjects (34\%) state that a maximum of 1 to 2 , or 3 to 5 reports of adverse events were made during the last year, 18 subjects (18\%) claim that there were no reports, while 1 subject states that there were 11 to 20, or 21 or more reports (Figure 3).

\section{Discussion}

The research conducted in the University Hospital Centre Osijek which included the opinions of 100 nurses regarding adverse events, including bedsores, falls, nosocomial infections, insufficient hand hygiene and adverse drug side effects, showed that nurses are active in improving the safety culture (82\%) and they believe it is acceptable (57.1\%). A similar study was conducted in California, in 232 acute hospitals, and it covered adverse events, including patient falls/

\section{Table 9. Subject responses regarding the claims related to the hospital in which they work}

\begin{tabular}{|c|c|c|c|c|c|c|}
\hline & \multicolumn{6}{|c|}{ Number (\%) of subjects } \\
\hline & $\begin{array}{l}\text { Strongly } \\
\text { disagree }\end{array}$ & Disagree & Neutral & Agree & $\begin{array}{l}\text { Strongly } \\
\text { agree }\end{array}$ & Total \\
\hline $\begin{array}{l}\text { Hospital management provides } \\
\text { a working environment which } \\
\text { promotes patient safety. }\end{array}$ & $\begin{array}{c}1 \\
(1)\end{array}$ & $\begin{array}{c}29 \\
(29.6)\end{array}$ & $\begin{array}{c}29 \\
(29.6)\end{array}$ & $\begin{array}{c}37 \\
(37.8)\end{array}$ & $\begin{array}{c}2 \\
(2)\end{array}$ & $\begin{array}{c}98 \\
(100)\end{array}$ \\
\hline Hospital wards cooperate. & 0 & $\begin{array}{c}13 \\
(13.1)\end{array}$ & $\begin{array}{c}21 \\
(21.2)\end{array}$ & $\begin{array}{c}63 \\
(63.6)\end{array}$ & $\begin{array}{c}2 \\
(2)\end{array}$ & $\begin{array}{c}99 \\
(100)\end{array}$ \\
\hline $\begin{array}{l}\text { Problems are "covered up" when } \\
\text { transferring from one ward to } \\
\text { another. }\end{array}$ & $\begin{array}{c}2 \\
(2.1)\end{array}$ & $\begin{array}{c}11 \\
(11.3)\end{array}$ & $\begin{array}{c}32 \\
(33)\end{array}$ & $\begin{array}{c}51 \\
(52.6)\end{array}$ & $\begin{array}{c}1 \\
(1)\end{array}$ & $\begin{array}{c}97 \\
(100)\end{array}$ \\
\hline
\end{tabular}




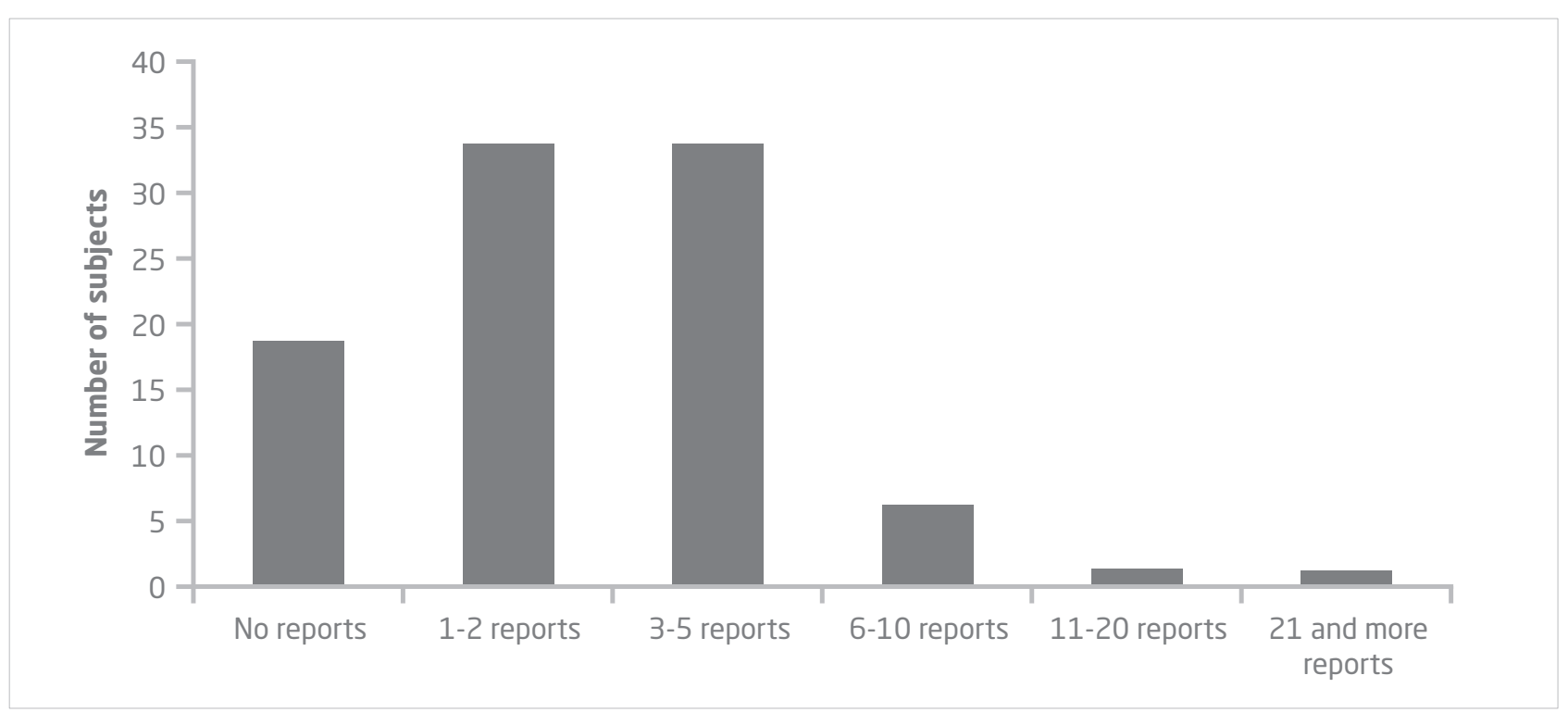

Figure 3. Distribution of reported adverse events in the last 12 months

injuries, bedsores, adverse drug side effects and nosocomial infections. A multilevel analysis researched the impact of nurses and patients, and hospital characteristics on the outcome of patient care. Results showed that patients do experience adverse events during their hospital stay, and that it is crucial that the number of adverse events decreases in the health system. Having an adequate nursing care is crucial in some cases (13). The results obtained in the University Hospital Centre Osijek show that highly educated nurses and persons holding a Bachelor's degree report adverse events more frequently (45.9\%), and that they work longer than it is necessary in order to give the best possible care to a patient (61.7\%). Another study which analysed reports of adverse events showed that subjects usually work longer than agreed and that about $40 \%$ of the 5,317 shifts exceeded the shift of 12 hours. Risks of error significantly increase when nurses work shifts longer than 12 hours, work overtime or work more than 40 hours a week (14). The research shows that a total of $71(71.7 \%)$ subjects feel that mistakes reflect on them, and 65 $(67.7 \%)$ of subjects agree with the statement that the mistakes led to positive changes. 72 subjects $(72.7 \%)$ agree with the claim that serious mistakes do not happen, instead they are just a coincidence, and 70 subjects (72.1\%) state that the other ward helps out if one ward is truly busy. When an adverse event is reported, a total of 72 subjects (74.2\%) considers it as a report against them, and not a report of a problem. After the changes were made to improve the safety of patients, 81 subjects (83.5\%) assessed their effectiveness. 74 subjects (76.3\%) stated that a lot of things were required to be done too fast, and too many of them as well, and 39 subjects $(40.3 \%)$ stated that they have sacrificed the safety of a patient in order to get more work done. A total of 34 subjects (33.4\%) stated that they had a problem with the patient safety culture in their ward, and only $50 \%$ of subjects agreed with the claim that procedures and system in place were good at preventing errors. The US Agency for Healthcare Research and Quality (AH$\mathrm{RQ}$ ) released a report in 2014 and the data was gathered from 653 hospitals. A total of 405,281 subjects participated in the research, of which $35 \%$ were licensed nurses. The results showed that in all working units ( $81 \%$ of positive answers) teamwork was present and that staff there respects each other. When it comes to claims regarding superiors, their expectations and activities that promote patient safety, 76\% of subjects think that the supervisor took into consideration the suggestions for improving patient safety and praised the staff for monitoring patients and following safety procedures. Subjects agree that mistakes led to positive changes, and changes were related to efficiency. The result of the adverse events reporting (44\%) was that the staff did not feel that their mistakes and reports of adverse event were directed against them. A total of $47 \%$ of subjects shared what extent of important information was passed on to hospital units during a shift change. The lack of communication between health professionals and 
their lack of synchronisation negatively affect the speed of patient recovery, reduction of the incidence of adverse events, and the lowering of treatment cost (15). Regarding the claim related to employment, $55 \%$ of subjects spoke about the sufficiency of staff and working hours, believing they were appropriate to provide the best nursing care to patients. In the survey of nurses in the University Hospital Centre Osijek results showed that only $10 \%$ of respondents agree that they have enough staff to do the job. Smaller American hospitals had the highest percentage of subjects who rated patient safety as excellent, and $81 \%$ of subjects rated it as very good. In major US hospitals, $71 \%$ of subjects rated it with the lowest mark, while in the University Hospital Centre Osijek most of the subjects (57.1\%) think it is acceptable. Subjects who work in the field of rehabilitation had the highest percentage of positive responses (70\%) and employees of emergency medical services had the lowest percentage (59\%) of positive responses. Rehabilitation had the highest percentage of subjects who, in their working area/unit, rated patient safety as excellent or very good (86\%). Emergency medical services had the lowest score $(65 \%)$. The intensive care unit (any type) had the highest percentage of subjects who reported one or more adverse events in the past year (61\%), while the rehabilitation had the lowest percentage (38\%). Responses of subjects who are in direct contact with the patients (49\%) are more positive than the ones who are not in direct contact with the patients (42\%), but they gave fewer positive marks regarding the support of administration for patient safety (71\%) compared to those without direct interaction (77\%). The results of the study showed that 39 subjects (39.8\%) strongly agree or agree with the statement that the hospital management provides a working environment that promotes patient safety, and 65 subjects (65.6\%) agreed with the statement that wards collaborate with each other, while 52 subjects (53.6\%) stated that the problems are "covered up" when transferring from one ward to another. Subjects in US hospitals with less than one year of experience had the highest percentage of positive responses (68\%) and subjects with one to ten years of experience had the lowest percentage ( $63 \%$ positive). Among subjects who had less than a year of work experience, $82 \%$ of them rated patient safety as excellent or very good (16). Subjects with one to five years of work experience have the lowest $(74 \%)$ percentage. A total of $47 \%$ of subjects with six to ten years of experience in their field of work re- ported one or more adverse events in the last year. Subjects with less than a year of work experience had the lowest (30\%) percentage of the adverse event reporting. The results showed that the majority of subjects have 11-20 years of work experience, and that subjects with 20 or more years of work experience reported adverse events more frequently. A trend analysis of over 359 US hospitals that submitted data on patient safety showed improvement of 1-3 per cent in relation to the report from 2014. The US Agency also published a report for 2016. A total of 680 US hospitals with a total of 447,584 patients had submitted data, of which the largest group (36\%) is made up from licensed nurses with an average of six years of work experience. $82 \%$ of subjects agree that they support each other and treat each other with respect, and $78 \%$ of subjects agree with the statement that their supervisor accepts suggestions for improving patient safety. A total of $73 \%$ of subjects agree that errors led to positive changes, while $55 \%$ of subjects agree with the statement that they feel as if the reported adverse event focused on them. A total of $48 \%$ of subjects agree that the relevant information is communicated during the transfer and handover of shift, while $54 \%$ believe that there is enough staff for the job. Smaller hospitals (up to 50 hospital beds) evaluated the safety of patients with excellent and very good grades (83\%), and larger hospitals (300 to 500 hospital beds) evaluated the safety of patients with the lowest grade (70\%). Subjects from non-surgical departments rated patient safety with higher grades (79\%) than emergency medical services or the intensive care unit which also reported the highest number of adverse events (one or more) in the last 12 months. Subjects who have been working for less than one year gave a better grade $(69 \%)$ than those who have been working for ten years (63\%). Subjects who have been working for over 20 years reported adverse events more often than those who have been working for one year, and subjects who work in surgical departments and in anaesthesiology increased their grade by an average of $4 \%$, i.e. they reported one or more adverse events in the last 12 months (17). The result analysis showed that 36 subjects (36\%) stated that in the last 12 months 1 to 2 or 3 to 5 reports of adverse events were made in the University Hospital Centre Osijek, while 20 subjects (20\%) stated that there was no such report. One subject stated that there were 11 to 20 or 21 or more reports. 


\section{Conclusions}

The conducted research drew the following main conclusions:

1. Nurses are active in improving the patient safety culture (82\%), and they rate it as acceptable (57.1\%).

2. Nurses agree that they do not have enough staff, but only $50 \%$ of subjects agree with the statement that the system is good in preventing adverse events.

3. The majority of subjects (74.2\%) feel that the report of adverse event is a report against them, and not reporting an adverse event is a problem in their job.

4. Highly educated nurses and persons with university degrees report adverse events more frequently and they feel that during high stress periods they have to work faster and shorten the procedure.

5. The majority of subjects (86\%) agree that they help each other out, and that they treat each other with respect (47\%).

6. Only $40 \%$ of subjects agree with the statement that the hospital administration promotes the patient safety culture.

7. Patient safety is an ethical imperative in all nursing care proceedings.

The quality of nursing care needs to be further examined in future research and even more significant parameters which influence the outcomes of nursing care should be encompassed, as well as nurses themselves and hospitals in which they work.

\section{References}

1. World Health Organisation. Patient safety curriculum guide: multi-professional edition. Available from: http://apps.who. int/iris/bitstream/10665/44641/1/9789241501958_ eng.pdf.Date of access: 1. 2. 2016.

2. European Commission Special Eurobarometer. Patient safety and quality of healthcare: summary report. Available form: http://ec.europa.eu/public_opinion/archives ebs/ebs_327_sum_en.pdf. Date of access: 3. 1. 2016

3. Mesarić J, Šimić D, Hadžić Kostrenčić C. Zbirno izvješće o pokazateljima sigurnosti pacijenta: siječanj - prosinac 2013. Agencija za kvalitetu i akreditaciju u zdravstvu i socijalnoj skrbi, 2014;1-74. Croatian.

4. Narodne novine. Zakon o kvaliteti zdravstvene zaštite. 2007: br 017. Croatian.

5. Hrvatska udruga medicinskih sestara. 5. konferencija Društva za kvalitetu:Analiza rizika iz sestrinske dokumentacije. Koprivnica, 2015.

6. American nurses association. Creating a culture of safety. Available from: http://www.nursingworld.org/ cultureofsafetyDate of access: 24. 5. 2016.

7. Lachman VD. Patient safety: The ethical imperative. Medsurg Nursing. 2007; 16:6;401-3.

8. Grgurević, D. Dekubitus u zdravstvenoj njezi kardioloških bolesnika. Cardiol Croat. 2014; 9 (9-10):501. Croatian.

9. Bokšić, T. Kontrola kvalitete zdravstvene njege na Klinici za neurokirurgiju. Zagreb, Available form: http://sestrinstvo.kbcsm.hr/ Croatian. Date of access: 27. 12. 2015.

10. Barbir, T. Zašto je važno spriječiti infekcije povezane sa zdravstvenom skrbi? Available form: http://sestrinstvo.kbcsm.hr/ Croatian. Date of access: 29. 12. 2015.

11. Narodne novine. Pravilnik o standardima kvalitete zdravstvene zaštite i načinu njihove primjene. 2011: br 79.

12. Hrvatska udruga medicinskih sestara. 1. konferencija o sigurnosti pacijenata i kvaliteti rada u sestrinstvu: Sinergija sigurnosti pacijenata i kontrole infekcija u upravljanju rizicima. Zagreb, 2015.

13. Cho S-H, Ketefian S, Barkauskas V, Smith, D. The effects of nurse staffing on adverse events, morbidity, mortality, and medical costs. Nurs Res. 2003; 52 (2): 71 - 9.

14. Rogers A, Hwang W-T, Scott L, Aiken LH, Dinges. The working hours of hospital staff nurses and patient safety. Health affairs. 2004; 23 (4): 203-12.

15. Mičević M, Mraović G, Friganović A. Aortokoronarna premosnica - čimbenici grane sestrinstva za poboljšanje tijeka liječenja. Sestrinski glasnik. 2016; 21: 28 - 32.

16. Agency for healthcare research and quality. Executive summary. Available from: http://www.ahrq.gov/professionals/quality- patientsafety/patientsafetyculture/hospital/2014/hosp14summ.htmIDate of access: 28. 12. 2015.

17. Westat R et al. Hospital Survey on Patient Safety Culture: 2016 User Comparative Database Report. AHRQ Publication. 2016;16 - 0021. 


\section{MIŠLJENJA MEDICINSKIH SESTRA I TEHNIČARA O IZVJEŠĆIVANJU O NEŽELJENIM DOGADAJIMA TIJEKOM PROCESA SESTRINSKE SKRBI}

\section{Sažetak}

Uvod. Sigurnost pacijenata predstavlja najpouzdaniju mjeru kvalitete rada u sestrinstvu. Najčešći su neželjeni događaji povezani s procesom sestrinske skrbi dekubitus, padovi, intrahospitalne infekcije, nedostatna higijena ruku i neželjeni događaji povezani s primjenom lijekova.

Cilj. Cilj je ovoga istraživanja ispitati mišljenja ispitanika o neželjenim događajima tijekom procesa sestrinske skrbi u Kliničkom bolničkom centru Osijek.

Ispitanici i metode. Provedeno je kvantitativno istraživanje s pomoću anonimne ankete koja je obuhvatila 100 medicinskih sestra/tehničara u veljači i ožujku 2016. na klinikama za kirurgiju, internu medicinu, anesteziologiju i neurologiju te u jedinici intenzivnog liječenja i hitnom prijemu.

Rezultati. Istraživanje je pokazalo da su medicinske sestre aktivne u poboljšanju kulture sigurnosti pacijenata (82 \% ispitanika). Čak 71,7 \% medicinskih sestara misli da se pogreške odražavaju na njih, dok se $67,7 \%$ ispitanika složilo s tvrdnjom da su pogreške dovele do pozitivnih promjena. Kada se neželjeni događaj prijavi, 74,2 \% ispitanika osjeća kako su oni osobno prijavljeni, a ne sami događaj. Nakon što naprave promjene kako bi poboljšale sigurnost pacijenata, 83,5 \% medicinskih sestara procjenjuje njihovu učinkovitost. Ispitanici, njih 33,4 \%, tvrde kako imaju problem u sigurnosti pacijenata u svojem okruženju, a 49 (50 \%) ispitanika tvrdi da je sustav dobar u sprječavanju neželjenih događaja. Većina ispitanika (57,1\%) ocjenjuje sigurnost pacijenata prihvatljivom. U sličnim istraživanjima koja su provedena u bolnicama SAD-a općenito je veća razina kulture sigurnosti pacijenata za nekoliko ocjenskih bodova.

Zaključak. Medicinske sestre / medicinski tehničari slažu se kako je kultura sigurnosti pacijenata s obzirom na neželjene događaje povezane s procesom sestrinske skrbi prihvatljiva te da su odgovorni za zaštitu i poboljšanje sigurnosti pacijenata.

Ključne riječi: neželjeni događaji, sestrinska skrb, sigurnost pacijenata 